\title{
The impact of obesity on cardiovascular structure and function: the fetal programming era
}

This article was published in the following Dove Press journal:

Pediatric Health, Medicine and Therapeutics

15 March 2012

Number of times this article has been viewed

Julie St-Pierre'

Luigi Bouchard ${ }^{2,3}$

Paul Poirier ${ }^{4}$

'Department of Pediatrics, Chicoutimi Hospital, Saguenay,

QC, Canada; ${ }^{2}$ Department of Biochemistry, Université de Sherbrooke, Sherbrooke, QC, Canada; ${ }^{3}$ ECOGENE-2।

and Lipid Clinic, Chicoutimi Hospital, Saguenay, QC, Canada; ${ }^{4}$ Quebec Heart and Lungs Institute, Université Laval,

Quebec, QC, Canada
Correspondence: Julie St-Pierre Chicoutimi Hospital, Department of Pediatrics, 305 St Vallier Street, CP 5006, Chicoutimi, Quebec, G7H 5H6, Canada $\mathrm{Tel}+$ I 4185491049

Fax + I 4186964673

Email julie.st-pierre@recherche-caurc.org

\begin{abstract}
The burden of obesity is now well established as a precursor of cardiovascular disease and other disorders. Although better clinical guidelines exist to prevent and treat obesity, the prevalence of obesity among children and adolescents is increasing alarmingly. Primary prevention remains the gold standard to significantly reduce the public health concerns associated with obesity. Traditional cardiovascular disease risk factors (such as dyslipidemia, hypertension, type 2 diabetes) for cardiovascular disease among children and adolescents are known. The scope of this review is thus to discuss new and emerging obesity and associated-disease risk factors. Evaluation of the coronary plaque formation, diastolic dysfunction, carotid intima-media thickness and heart rate variability represent interesting tools with clinical relevance. Beyond these new cardiovascular disease risk factors, recent evidence suggests that a detrimental fetal environment, associated with for example, maternal obesity, insulin resistance, and physical inactivity, imprints fetal metabolic programming via epigenetic mechanisms that predisposes the newborn to obesity and cardiovascular disease later in life. This information may impact on the future management of maternal health, as well as for those high-risk children.
\end{abstract}

Keywords: cardiovascular disease, pediatrics, risk factors

\section{Introduction}

Obesity is one of the key features of the metabolic syndrome. The latter is a constellation of cardiovascular disease (CAD) risk factors including dyslipidemia, hypertension, and hyperglycemia, a precursor of type 2 diabetes. ${ }^{1,2}$ Obesity has now reached an epidemic proportion not only in adults, but also in children, and especially young adults. ${ }^{3,4}$ For example, the obesity prevalence in the pediatric population of the United States has increased to $17 \%$ (body mass index [BMI]-for-age $\geq$ the 95 th percentile on Centers for Disease Control and Prevention [CDC] growth charts) with 35\% of children and adolescents being considered overweight (BMI-for-age $\geq$ the 85 th percentile). The picture is not better worldwide with more than 42 million obese children. ${ }^{5}$ Because of the burden of the obesity epidemic, ${ }^{6,7}$ and because its prevalence keeps growing in high-risk populations, ${ }^{8}$ the objective of the present review is to discuss new and early evidence that outreaches our current, and more traditional understanding of lipids, blood pressure, and insulin/glucose metabolisms.

Increasing evidence suggests that obesity and its associated metabolic complications ${ }^{9}$ have a fetal origin. ${ }^{10}$ This intrauterine programming influence may be attributable to different maternal factors, including nutritional status, maternal weight and levels of blood lipids, glucose, and insulin. ${ }^{11-13}$ It has been shown that the exposure to a deleterious fetal environment affects the organogenesis as well as the epigenetic profile. ${ }^{14}$ Since submit your manuscript | www.dovepress.com

Dovepress

http://dx.doi.org//0.2147/PHMT.SI2931
Pediatric Health, Medicine and Therapeutics 2012:3 I-8

(C) 2012 St-Pierre et al, publisher and licensee Dove Medical Press Ltd. This is an Open Access article which permits unrestricted noncommercial use, provided the original work is properly cited. 
obesity itself is a risk factor for pregnancy complications (gestational diabetes and pre-eclampsia), both of these early mechanisms (gestational diabetes and pre-eclampsia) have the potential to fuel the current obesity epidemic. In addition, these fetal programming factors induce cellular adaptative responses and some tissue-specific cells may be more vulnerable to these intrauterine environmental challenges. Heart rate variability, carotid intima-media thickness, left ventricular dysfunction, as well as coronary plaque formation and lipid abnormalities seen in obese children, are non-traditional cardiovascular disease risk factors and will be discussed in the present review. These non-traditional risk factors may have emerged from fetal programming factors and may represent in the future earlier cardiovascular disease markers among obese children and adolescents. The risk of long-term cardiometabolic complications among the obese pediatric population varies from one child to another. In that sense, there is a need to identify earlier non-traditional cardiovascular markers to identify higher-risk patients.

\section{Traditional cardiovascular risk factors among children and adolescents}

In the last decade, the obesity, dyslipidemic, hypertensive, and hyperinsulinemic phenotypes have been studied and well described among children and adolescents in the United States (Table 1). ${ }^{15}$ Pediatric obesity was defined as a $\mathrm{BMI}>$ the 95 th percentile and those $>$ the 85 th percentile are considered at risk of being overweight. ${ }^{16}$ Abnormal lipid profile is defined in children and adolescents by total cholesterol $>170 \mathrm{mg} / \mathrm{dL}(4.4 \mathrm{mmol} / \mathrm{L})$, and/or low-density lipoprotein cholesterol (LDL-C) $>110 \mathrm{mg} / \mathrm{dL}(2.8 \mathrm{mmol} / \mathrm{L})$, and/or triglycerides $>150 \mathrm{mg} / \mathrm{dL}(1.7 \mathrm{mmol} / \mathrm{L})$, and/or high density lipoprotein cholesterol (HDL-C) $<35 \mathrm{mg} / \mathrm{dL}$ $(0.91 \mathrm{mmol} / \mathrm{L}) \cdot{ }^{17-20}$ By convention, hypertension in young people is defined by a blood pressure $>$ the 90th percentile

Table I Traditional risk factors for cardiovascular disease among children and adolescents

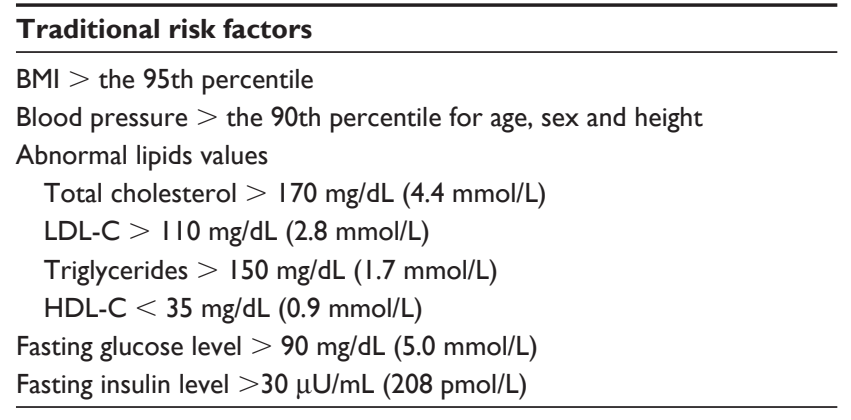

Abbreviations: BMI, body mass index; LDL-C, low-density lipoprotein cholesterol; HDL-C, high-density lipoprotein cholesterol. for age, sex, and height. ${ }^{21}$ Finally, with an increased incidence due mainly to the obesity epidemic, impaired glucose tolerance was found to be as high as $25 \%$ in obese children and adolescents. In a study of young patients with impaired glucose tolerance, half of them were found to have an increased fasting insulin level. ${ }^{22}$ Values of reference for fasting glucose, insulin concentrations, and impaired glucose tolerance may vary upon ethnicity and were published a few years ago. ${ }^{23}$ It is now recognized that the prevalence of these traditional cardiovascular risk factors (Table 1) increases at a very fast pace among children and adolescents. The environmental changes (physical inactivity and/or high-carbohydrates diet, for example) that took place in the last decades clearly put contemporary children and adolescents at increased risk of obesity and its related metabolic complications. However, there is a need to also determine and understand the impacts of non-traditional CAD risk factors if we want to offer better prevention programs and treatments to these children and adolescents.

\section{The rebound of adiposity and Barker's hypothesis}

More than 20 years ago, David Barker and his collaborators suggested that CAD might have a fetal origin. ${ }^{24}$ They conducted a retrospective study among 5654 men born between 1911 and 1930 in Hertfordshire (England) and showed a strong relationship between low birth weight, as well as low weight at 1 year of age, and highest adult death rates from ischemic heart disease. ${ }^{24}$ Later, in a landmark article, they reaffirmed their hypothesis and also discussed factors determining growth at critical periods of the fetal life, especially hormones and growth factors that might be responsible for a disproportionate fetal growth similar to that seen with undernutrition. ${ }^{25}$

The impact of newborn growth on CAD risk profile has also been explored. The Helsinki Study analyzed 8760 people born between 1934 and 1944. Results revealed that those who were small for their gestational age at birth and thin at 2 years of age, who rapidly put on weight after 2 years, were also those who were at a highest risk for ischemic heart disease in adulthood. ${ }^{10}$ This finding refers to the "rebound of adiposity" concept by which the rapid weight catch-up phenomenon after the age of two is associated with adult obesity, type 2 diabetes, hypertension, and cardiovascular disease. ${ }^{10}$

Additionally, the Bogalusa Heart Study of 204 autopsies of young people aged between 2 and 39 years clearly demonstrates that artery fatty streaks and fibrous plaque associated with ischemic heart events start to develop before the age of 
15 years and as soon as 2 years of age.${ }^{26}$ One may think that this is part of the natural process of aging, but this matter essentially points to a very early onset of the atherosclerotic process.

Barker's hypothesis as well as the Helsinki and Bogalusa studies suggest that early fetal and perinatal determinants may be responsible for adult ischemic disease. Cardiomyocytes, blood vessels, and adipocytes may be vulnerable to in utero and perinatal factors, such as malnutrition, lack of maternal physical activity, maternal hormones, and inappropriate weight. The biological mechanisms linking fetal exposure to a detrimental environment are not yet well understood. However, the epigenetic programming of key cellular functions related to energy metabolism and inflammation has been suggested as a key factor in order to understand why newborns of mothers with obesity, physical inactivity, gestational diabetes, and/or malnutrition are at a higher risk for obesity, diabetes, and CAD later in life. ${ }^{27}$

In addition, obesity and its related metabolic complications have been shown to have a significant heritability component going up to $50 \%$ for some phenotypes such as abdominal obesity. ${ }^{28}$ Nevertheless, although few severe obesity causative genes (leptin, leptin receptor, and melanocortin 4 receptor [MC4R]) have been identified, it is now well accepted that "common" obesity is the result of the interaction of multiple genes with the environment, each having a small effect size. ${ }^{29}$ Altogether, gene polymorphisms only account for a small fraction of the variance of the traits suggesting that other genes and molecular mechanisms such as epigenetics remain to be identified. ${ }^{30}$

\section{Epigenetics and fetal programming}

Epigenetics refers to molecular mechanisms dedicated to the regulation of gene transcription. DNA methylation is the most stable and best understood epigenetic system. ${ }^{31}$ It is usually found within the regulatory regions of most of the transcribed genes. ${ }^{32,33}$ DNA methylation is the addition of a methyl group (CH3) at the cytosines (Cmet) located just upstream from a guanine ( $\mathrm{CpG}$ dinucleotides). Put simply, DNA methylation does not change the (letter) sequence (letter) of the DNA; it changes how the genetic information is interpreted.

DNA methylation has fostered considerable attention recently. It came following the demonstration that the addition or the erasure of the methyl group at $\mathrm{CpG}$ loci is made in response to a number of environmental stimuli such as the in utero environment. ${ }^{34-36}$ The DNA methylation profile can also be stable over time (mitotically-stable) (some marks can be short-lived and rapidly reversed), producing long-term changes to gene expression and thus protein synthesis. ${ }^{37}$ Since the phenotype of an individual is largely dependent on the amount of each protein composing his/her cells, tissues and organs, DNA methylation changes could therefore have profound phenotypic effects. ${ }^{38}$ Accordingly, DNA methylation has the potential to highlight central pathophysiological processes involved in obesity, diabetes, and CAD development.

The results of a few studies have underlined the importance of epigenetics in the etiology and development of CAD risk factors..$^{34,36,39-45}$ Recently, we have shown that newborn DNA methylation adaptations at the leptin and adiponectin genes are associated with glucose concentrations and metabolism status during pregnancy. ${ }^{14,46} \mathrm{Up}$ to 98 women were recruited at their first trimester of pregnancy and were followed until delivery. Maternal blood samples were collected at the end of each trimester of pregnancy and at delivery. At the first trimester of pregnancy, the women were slightly overweight, and generally metabolically healthy, all having a normal fasting glucose concentration. However, about a third of them were classified as having impaired glucose tolerance at the end of the second trimester of pregnancy according to the World Health Organization (WHO) guidelines. ${ }^{47}$ At delivery, placenta and cord blood samples were collected along with the measurements of the newborn anthropometric and metabolic parameters. On average, the newborns were of normal weight at birth $(3.42 \pm 0.5 \mathrm{~kg})$ and metabolically healthy. Briefly, we have shown that the placenta leptin gene promoter DNA methylation level was correlated with the maternal 2-hour post-oral glucose tolerance test (OGTT) glycemia. ${ }^{14}$ As expected, the leptin gene expression levels were negatively correlated with DNA methylation levels in the placenta. This is suggestive of a functional impact of maternal hyperglycemia-associated DNA methylation changes. Very similar observations were made for adiponectin. ${ }^{46}$ Placenta adiponectin promoter DNA methylation levels were negatively correlated with glucose levels ( 2 hours post-OGTT) and with the mothers' circulating adiponectin concentration at each trimester of pregnancy trimester as well as 24 hours post-delivery, suggestive of a functional impact of these epigenetic changes. Since leptin and adiponectin are two of the most potentially important adipose tissue-derived hormones regulating appetite and energy expenditure, epigenetic changes at these two gene loci, if long-lasting, have the potential to alter the energy balance regulation, and therefore, the newborn's risk to develop obesity later in life. In addition, we have shown that DNA methylation variability at the insulin-like growth factor 2 (IGF2) gene locus 
was associated with birth weight and other markers of fetal growth and development. ${ }^{48}$ These IGF2 data emphasize the importance of this gene as an early important obesity determinant, because it is well established that birth weight and weight-gain profile in the first year of life are associated with an increased risk to develop the metabolic syndrome later in life. ${ }^{10} \mathrm{~A}$ few other groups reported similar observations in humans, ${ }^{34,36,49,50}$ but the field clearly needs additional studies. Nevertheless, a new obesity developmental model based on fetal programming and epigenetics is emerging. ${ }^{51}$

Other natural adaptative mechanisms are thought to imprint structural and functional changes among cardiomyocytes and tissue-specific cells (blood vessels and adipose tissue, for instance). These potential changes may predispose to $\mathrm{CAD}$ and are reviewed in the following sections.

\section{Coronary plaque formation and lipid anomalies in obese children and adolescents}

In 1965, Eggen et al were the first to associate the presence of coronary calcifications with significant clinical coronary lesions. ${ }^{52}$ These coronary calcifications are also referred to as the "atherosclerotic plaque". The plaque forms progressively in arteries through different mechanisms. In particular, intracellular signaling processes are upregulated and modify the smooth muscle cells found in arteries into powerful proinflammatory cells. They later recruit cytokines, lipids, and other mediators that contribute over time to the progression and eventually rupture of the plaque. Scientists have known for decades that this atherosclerotic process starts at an early age. ${ }^{26,53,54}$ Investigators from the Muscatine Heart Study ${ }^{53}$ and others ${ }^{55}$ have demonstrated that traditional CAD risk factors, ${ }^{55}$ such as high triglycerides, hypertension, increased BMI, high LDL-C, as well as elevated apolipoprotein B concentrations, are all associated with the presence of atherosclerotic plaques in young asymptomatic men and women. ${ }^{53,55}$ This finding was found to be predictive of CAD events later in the adult life. ${ }^{26}$

Due to a molecular defect in the HMGcoA reductase gene, familial hypercholesterolemia is a good model to study this accelerated atherosclerotic process. In this autosomal dominant condition, high levels of LDL-C accumulate in the arterial wall and prematurely stimulate the formation of severe atherosclerosis via pro-inflammation processes. However, numerous environmental factors, such as poor diet, tobacco smoking, and obesity have been demonstrated to affect the clinical expression of atherosclerosis, ${ }^{56}$ and accelerate plaque formation even more. In the same manner, obese children and adolescents can have an accelerated atherosclerotic process in the presence of different environmental factors, but also in relation to detrimental prenatal and postnatal exposure to other factors. Clinicians should pay close attention to the familial history of dyslipidemia and the early familial history of CAD in obese children. A lipid profile should be obtained in children with significant familial history of CAD, as recommended by the American Heart Association and the American Academy of Pediatrics. ${ }^{57,58}$

\section{Diastolic dysfunction associated with pediatric obesity}

The Muscatine Heart Study has also revealed that excessive weight and high blood pressure were predictive of an altered left ventricular mass among children. ${ }^{53,59}$ Later, in a cohort of 49 healthy normal children aged 3-19 years, the presence of obesity was found to be associated with left ventricular dysfunction. ${ }^{60}$ In 2011, Dhuper et al reported that children and adolescents characterized by obesity and hypertension had concentric cardiac hypertrophy associated with left ventricular diastolic dysfunction. ${ }^{61}$ Evidence of cardiac remodeling in the obese adult population was prospectively demonstrated to be predictive of the later increased cardiovascular risk. ${ }^{62}$ In addition, weight loss induced by bariatric surgery restores normal cardiac structure and function altered by the presence of severe obesity. ${ }^{63}$ Whether left ventricular diastolic dysfunction is or is not an early predictor of the cardiovascular risk among obese children and adolescents remains to be shown prospectively in large cohorts. However, this new area of research looks promising to identify, with the use of a noninvasive method (echocardiography), higher-risk patients in the obese pediatric population.

\section{Carotid intima-media thickness in obese children and adolescents}

With such numerous hemodynamic and metabolic changes among obese children and adolescents, authors have speculated that this "domino effect" should impact on blood vessel elasticity. Since damaged carotid arteries have previously been shown to be predictive of cardiovascular outcomes, ${ }^{64}$ some authors hypothesized that carotid intima-media thickness and stiffness found in some obese and diabetic adult patients could develop earlier in life. In this regard, 96 adolescents referred in a pediatric center for 24-hour ambulatory blood pressure monitoring, who were also obese, were found to have significantly thicker internal carotids compared to normal controls. ${ }^{64,65}$ Another ultrasound carotid artery study including 446 lean, obese, and type 2 diabetic youths 
demonstrated that not only were the carotids of the two latter groups thicker, they were also stiffer than those of the lean control group. ${ }^{66}$ This positive relationship between carotid intima-media thickness, and obesity or type 2 diabetes, increases with age. These data add credit to previous results obtained in the Bogalusa and the Muscatine studies. ${ }^{26,53}$ In retrospect, it clearly indicates that early physiological and pro-atherosclerotic changes occur in young obese and/or diabetic patients and therefore could significantly increase their risk for any cardiovascular event later in their adult life. ${ }^{26}$ However, it is important to emphasize that not every obese child or adolescent shares the same lifetime risk of CAD. The carotid intima-media measurement in obese children and adolescents may constitute a powerful marker not only of the long-term risk of CAD, but also of morbidity and mortality.

\section{Heart rate variability and physical capacity in obese children and adolescents}

Since obesity and hypertension induce structural and metabolic changes in young individuals, it was proposed that a disturbance of the sympathetic nervous system control could also be encountered. ${ }^{67}$ The measurement of heart rate variability was shown to be a good way to assess autonomic nervous system imbalances, cardiovascular diseases, and mortality ${ }^{68}$ Heart rate variability is a physiological phenomenon and a predictor of mortality in the adult population after myocardial infarction. ${ }^{69,70}$ It was found to be altered early in obese children. ${ }^{71}$ The autonomic nervous system control and the physical activity of young obese individuals are modified even before puberty. ${ }^{71}$ Recent studies have shown that fetal cardiac sympathetic activation may be influenced, in part,

Table 2 Emerging or non-traditional risk factors of cardiovascular disease among obese children and adolescents

\begin{tabular}{l}
\hline Emerging risk factors \\
\hline Coronary plaque formation \\
(Familial history of premature CAD and/or dyslipidemia) \\
Carotid intima-media thickness \\
(Doppler measurement) \\
Left ventricular dysfunction \\
(Echocardiography) \\
Heart rate variability \\
(ECG recording) \\
Epigenetic and fetal markers \\
(Fetal blood-cord analyses and/or maternal detrimental \\
environmental factors)
\end{tabular}

Note: References for those non-traditional risk factors are cited in the text. Abbreviations: CAD, cardiovascular disease; ECG electrocardiogram. by pre-pregnancy maternal BMI and could represent a potential cardiovascular programming factor. ${ }^{72}$ Again, this emerging tool may represent a non-invasive instrument to investigate obese children and adolescents at higher risk of CAD.

\section{Conclusion}

The Coronary Heart Disease Policy Model, a state-transition computer simulation used in the United States, has projected that by 2020 , the present overweight phenomenon in the adolescent population will increase the prevalence of obese 35 -year-old men from $30 \%$ to $37 \%$ and $34 \%$ to $44 \%$ in women. ${ }^{73}$ By 2035 , it was estimated that this projection will lead to a $5 \%-16 \%$ increased prevalence of cardiovascular disease, mainly caused by obesity. ${ }^{73}$ Despite more than 30 years of primary prevention in the adult population, behavior regarding cultural beliefs, food industry, and education remain major factors against obesity prevention and management. Because obesity prevention is a complex, multi-targeted intervention and a huge challenge for public health authorities, the American Academy of Pediatrics has already published multi-approach guidelines for the management of children and adolescents with obesity. ${ }^{74}$ Pediatric nutrition and physical activity guidelines for children have been validated but remain unknown and unfortunately underutilized. ${ }^{75-77}$ Even, the effect of obesity summer camps has been studied and has attracted a relative interest. ${ }^{78}$ At this point, we need to emphasize the availability and usefulness of such programs and disseminate information about them in the medical community.

The emerging novel clinical tools, such as carotid intimamedia determination by Carotid Doppler Ultrasonography in children, heart rate variability, and/or left ventricular diastolic dysfunction evaluation in obese children and adolescents, could contribute to identify higher-risk cardiovascular disease children and adolescents (Table 2). These high-risk patients could benefit from early identification, management, and referral to specialized multidisciplinary pediatric clinics (pediatricians, pediatric endocrinologists, pediatric cardiologists, nutritionists, and kinesiologists). In addition, to significantly reduce the obesity epidemic and its cardiovascular complications, close attention should also be also paid to prenatal and postnatal epigenetic phenomena. Emerging evidence of fetal programming shows that a broader approach should be developed to also include preventive programs targeted at pregnant women. In the future, other very interesting emerging fields, such as the microbiota, may also be considered in the individual response to anti-obesity molecules as well as potential modulators of the pro-inflammatory state 
seen in obese higher-risk CAD patients. ${ }^{79,80}$ At the present time, the growing and alarming obesity epidemic, as well as the traditional and non-traditional risk factors of CAD in children and adolescents across the world, should raise a more serious collective medical concern and urge every one of us to act now, by identifying these individuals, and to refer and treat them accordingly.

\section{Acknowledgments}

The authors thank Céline Bélanger for her thoughtful revision of the manuscript and Johannie Munger for her help in the manuscript editing process. Luigi Bouchard is a junior research scholar from the Fonds de la recherche en santé du Québec (FRSQ) and Paul Poirier is a senior research scholar from the Fonds de la recherche en santé du Québec (FRSQ).

\section{Disclosure}

The authors report no conflicts of interest in this work.

\section{References}

1. Lamarche B, Lemieux S, Dagenais GR, Després JP. Visceral obesity and the risk of ischaemic heart disease: insights from the Québec Cardiovascular Study. Growth Horm IGF Res. 1998;8(Suppl B):1-8.

2. Pouliot MC, Després JP, Lemieux S, et al. Waist circumference and abdominal sagittal diameter: best simple anthropometric indexes of abdominal visceral adipose tissue accumulation and related cardiovascular risk in men and women. Am J Cardiol. 1994;73(7):460-468.

3. Cornier MA, Després JP, Davis N, et al. Assessing adiposity: a scientific statement from the American Heart Association. Circulation. 2011;124(18):1996-2019.

4. Yach D, Stuckler D, Brownell KD. Epidemiologic and economic consequences of the global epidemics of obesity and diabetes. Nat Med. 2006;12(1):62-66.

5. Lobstein T, Baur L, Uauy R, IASO International Obesity TaskForce. Obesity in children and young people: a crisis in public health. Obes Rev. 2004;5 Suppl 1:4-104.

6. Anderson SE, Whitaker RC. Prevalence of obesity among US preschool children in different racial and ethnic groups. Arch Pediatr Adolesc Med. 2009;163(4):344-348.

7. Ogden CL, Carroll MD, Curtin LR, Lamb MM, Flegal KM. Prevalence of high body mass index in US children and adolescents, 2007-2008. JAMA. 2010;303(3):242-249.

8. Broyles S, Katzmarzyk PT, Srinivasan SR, et al. The pediatric obesity epidemic continues unabated in Bogalusa, Louisiana. Pediatrics. 2010;125(5):900-905.

9. Reaven GM. Banting lecture 1988. Role of insulin resistance in human disease. Diabetes. 1988;37(12):1595-1607.

10. Barker DJ, Osmond C, Forsén TJ, Kajantie E, Eriksson JG. Trajectories of growth among children who have coronary events as adults. $N$ Engl J Med. 2005;353(17):1802-1809.

11. Buchanan TA, Kjos SL. Gestational diabetes: risk or myth? J Clin Endocrinol Metab. 1999;84(6):1854-1857.

12. Dörner G, Plagemann A. Perinatal hyperinsulinism as possible predisposing factor for diabetes mellitus, obesity and enhanced cardiovascular risk in later life. Horm Metab Res. 1994;26(5):213-221.

13. McMillen IC, Robinson JS. Developmental origins of the metabolic syndrome: prediction, plasticity, and programming. Physiol Rev. 2005;85(2):571-633.
14. Bouchard L, Thibault S, Guay SP, et al. Leptin gene epigenetic adaptation to impaired glucose metabolism during pregnancy. Diabetes Care. 2010;33(11):2436-2441.

15. Steinberger J, Daniels SR. Obesity, insulin resistance, diabetes, and cardiovascular risk in children: an American Heart Association scientific statement from the Atherosclerosis, Hypertension, and Obesity in the Young Committee (Council on Cardiovascular Disease in the Young) and the Diabetes Committee (Council on Nutrition, Physical Activity, and Metabolism). Circulation. 2003;107(10):1448-1453.

16. Troiano RP, Flegal KM, Kuczmarski RJ, Campbell SM, Johnson CL. Overweight prevalence and trends for children and adolescents. The National Health and Nutrition Examination Surveys, 1963 to 1991. Arch Pediatr Adolesc Med. 1995;149(10):1085-1091.

17. Kavey RE, Daniels SR, Lauer RM, Atkins DL, Hayman LL, Taubert K. American Heart Association guidelines for primary prevention of atherosclerotic cardiovascular disease beginning in childhood. $J$ Pediatr. 2003;142(4):368-372.

18. Kavey RE, Daniels SR, Lauer RM, Atkins DL, Hayman LL, Taubert K. American Heart Association guidelines for primary prevention of atherosclerotic cardiovascular disease beginning in childhood. Circulation. 2003;107(11):1562-1566.

19. Cook S, Weitzman M, Auinger P, Nguyen M, Dietz WH. Prevalence of a metabolic syndrome phenotype in adolescents: findings from the third National Health and Nutrition Examination Survey, 1988-1994. Arch Pediatr Adolesc Med. 2003;157(8):821-827.

20. Shamir R, Lerner A, Fisher EA. Hypercholesterolemia in children. Isr Med Assoc J. 2000;2(10):767-771.

21. National High Blood Pressure Education Program Working Group on High Blood Pressure in Children and Adolescents. The fourth report on the diagnosis, evaluation, and treatment of high blood pressure in children and adolescents. Pediatrics. 2004;114(2 Suppl 4th Report):555-576.

22. Sinha R, Fisch G, Teague B, et al. Prevalence of impaired glucose tolerance among children and adolescents with marked obesity. $N$ Engl $J$ Med. 2002;346(11):802-810.

23. Weiss R, Dziura J, Burgert TS, et al. Obesity and the metabolic syndrome in children and adolescents. N Engl J Med. 2004;350(23):2362-2374.

24. Barker DJ, Winter PD, Osmond C, Margetts B, Simmonds SJ. Weight in infancy and death from ischaemic heart disease. Lancet. 1989;2(8663):577-580.

25. Barker DJ. Fetal origins of coronary heart disease. BMJ. 1995; 311(6998):171-174.

26. Berenson GS, Srinivasan SR, Bao W, Newman WP III, Tracy RE, Wattigney WA. Association between multiple cardiovascular risk factors and atherosclerosis in children and young adults. The Bogalusa Heart Study. N Engl J Med. 1998;338(23):1650-1656.

27. Symonds ME, Sebert SP, Hyatt MA, Budge H. Nutritional programming of the metabolic syndrome. Nat Rev Endocrinol. 2009;5(11):604-610.

28. Pérusse L, Després JP, Lemieux S, Rice T, Rao DC, Bouchard C. Familial aggregation of abdominal visceral fat level: results from the Quebec family study. Metabolism. 1996;45(3):378-382.

29. Pérusse L, Rankinen T, Zuberi A, et al. The human obesity gene map: the 2004 update. Obes Res. 2005;13(3):381-490.

30. Furrow RE, Christiansen FB, Feldman MW. Environment-sensitive epigenetics and the heritability of complex diseases. Genetics. 2011;189(4):1377-1387. Epub October 3, 2011.

31. Bird A. DNA methylation patterns and epigenetic memory. Genes Dev. 2002;16(1):6-21.

32. Bird AP. CpG-rich islands and the function of DNA methylation. Nature. 1986;321(6067):209-213.

33. Ghazi H, Gonzales FA, Jones PA. Methylation of CpG-islandcontaining genes in human sperm, fetal and adult tissues. Gene. 1992;114(2):203-210.

34. Heijmans BT, Tobi EW, Stein AD, et al. Persistent epigenetic differences associated with prenatal exposure to famine in humans. Proc Natl Acad Sci U S A. 2008;105(44):17046-17049. 
35. Jaenisch R, Bird A. Epigenetic regulation of gene expression: how the genome integrates intrinsic and environmental signals. Nat Genet. 2003;Suppl 33:245-254.

36. Tobi EW, Lumey LH, Talens RP, et al. DNA methylation differences after exposure to prenatal famine are common and timing- and sexspecific. Hum Mol Genet. 2009;18(21):4046-4053.

37. Kangaspeska S, Stride B, Métivier R, et al. Transient cyclical methylation of promoter DNA. Nature. 2008;452(7183):112-115.

38. Ling C, Del Guerra S, Lupi R, et al. Epigenetic regulation of PPARGC1A in human type 2 diabetic islets and effect on insulin secretion. Diabetologia. 2008;51(4):615-622.

39. Yuen RK, Avila L, Penaherrera MS, et al. Human placental-specific epipolymorphism and its association with adverse pregnancy outcomes. PLoS One. 2009;4(10):e7389.

40. Castro R, Rivera I, Struys EA, et al. Increased homocysteine and S-adenosylhomocysteine concentrations and DNA hypomethylation in vascular disease. Clin Chem. 2003;49(8):1292-1296.

41. Hiltunen MO, Turunen MP, Häkkinen TP, et al. DNA hypomethylation and methyltransferase expression in atherosclerotic lesions. Vasc Med. 2002;7(1):5-11.

42. Hiltunen MO, Yla-Herttuala S. DNA methylation, smooth muscle cells, and atherogenesis. Arterioscler Thromb Vasc Biol. 2003;23(10): 1750-1753.

43. Laukkanen MO, Mannermaa S, Hiltunen MO, et al. Local hypomethylation in atherosclerosis found in rabbit ec-sod gene. Arterioscler Thromb Vasc Biol. 1999;19(9):2171-2178.

44. Lund G, Andersson L, Lauria M, et al. DNA methylation polymorphisms precede any histological sign of atherosclerosis in mice lacking apolipoprotein E. J Biol Chem. 2004;279(28): 29147-29154.

45. Zaina S, Lindholm MW, Lund G. Nutrition and aberrant DNA methylation patterns in atherosclerosis: more than just hyperhomocysteinemia? J Nutr. 2005;135(1):5-8.

46. Bouchard L, Hivert MF, Guay SP, St-Pierre J, Perrron P, Brisson D. Placental adiponectin gene DNA methylation levels are associated with mothers' blood glucose concentration. Diabetes. 2012. In press.

47. WHO. Definition, diagnosis and classification of diabetes mellitus and its complications: Report of a WHO Consultation. Part 1: Diagnosis and Classification of Diabetes Mellitus. 1999. Available from: http://whqlibdoc.who.int/hq/1999/who_ncd_ncs_99.2.pdf. Accessed February 28, 2012.

48. St-Pierre J, Brisson D, Perron P, Poirier P, Bouchard L. IGF2 is a modulator of newborn's fetal growth and adiposity. Circulation. 2010;122:A19234.

49. Banister CE, Koestler DC, Maccani MA, Padbury JF, Houseman EA, Marsit CJ. Infant growth restriction is associated with distinct patterns of DNA methylation in human placentas. Epigenetics. 2011;(7):920-927.

50. Filiberto AC, Maccani MA, Koestler D, et al. Birthweight is associated with DNA promoter methylation of the glucocorticoid receptor in human placenta. Epigenetics. 2011;6(5):566-572.

51. Campión J, Milagro FI, Martinez JA. Individuality and epigenetics in obesity. Obes Rev. 2009;10(4):383-392.

52. Eggen DA, Strong JP, McGill HC Jr. Coronary calcification. Circulation. 1965;32(6):948-955.

53. Berenson GS, Wattigney WA, Tracy RE, et al. Atherosclerosis of the aorta and coronary arteries and cardiovascular risk factors in persons aged 6 to 30 years and studied at necropsy (The Bogalusa Heart Study). Am J Cardiol. 1992;70(9):851-858.

54. Newman WP III, Freedman DS, Voors AW, et al. Relation of serum lipoprotein levels and systolic blood pressure to early atherosclerosis. The Bogalusa Heart Study. NEngl J Med. 1986;314(3): $138-144$.

55. Mahoney LT, Burns TL, Stanford W, et al. Coronary risk factors measured in childhood and young adult life are associated with coronary artery calcification in young adults: the Muscatine Study. J Am Coll Cardiol. 1996;27(2):277-284.
56. Doevendans PA, Jukema W, Spiering W, Defesche JC, Kastelein JJ. Molecular genetics and gene expression in atherosclerosis. Int J Cardiol. 2001;80(2-3):161-172.

57. Expert Panel on Integrated Guidelines for Cardiovascular Health and Risk Reduction in Children and Adolescents; National Heart, Lung, and Blood Institute. Expert panel on integrated guidelines for cardiovascular health and risk reduction in children and adolescents: summary report. Pediatrics. 2011;128(Suppl 5):S213-S256.

58. McCrindle BW, American Heart Association Atherosclerosis, Hypertension, and Obesity in Youth Committee; American Heart Association Council of Cardiovascular Disease in the Young; American Heart Association Council on Cardiovascular Nursing, et al. Drug therapy of high-risk lipid abnormalities in children and adolescents: a scientific statement from the American Heart Association Atherosclerosis, Hypertension, and Obesity in Youth Committee, Council of Cardiovascular Disease in the Young, with the Council on Cardiovascular Nursing. Circulation. 2007;115(14):1948-1967.

59. Janz KF, Burns TL, Mahoney LT. Predictors of left ventricular mass and resting blood pressure in children: the Muscatine Study. Med Sci Sports Exerc. 1995;27(6):818-825.

60. Mehta SK, Richards N, Lorber R, Rosenthal GL. Abdominal obesity, waist circumference, body mass index, and echocardiographic measures in children and adolescents. Congenit Heart Dis. 2009;4(5):338-347.

61. Dhuper S, Abdullah RA, Weichbrod L, Mahdi E, Cohen HW. Association of obesity and hypertension with left ventricular geometry and function in children and adolescents. Obesity (Silver Spring). 2011;19(1):128-133.

62. Lieb W, Xanthakis V, Sullivan LM, et al. Longitudinal tracking of left ventricular mass over the adult life course: clinical correlates of shortand long-term change in the framingham offspring study. Circulation. 2009;119(24):3085-3092.

63. Poirier P, Martin J, Marceau P, Biron S, Marceau S. Impact of bariatric surgery on cardiac structure, function and clinical manifestations in morbid obesity. Expert Rev Cardiovasc Ther. 2004;2(2):193-201.

64. Ali YS, Rembold KE, Weaver B, et al. Prediction of major adverse cardiovascular events by age-normalized carotid intimal medial thickness. Atherosclerosis. 2006;187(1):186-190. Epub October 17, 2005.

65. Stabouli S, Kotsis V, Papamichael C, Constantopoulos A, Zakopoulos N. Adolescent obesity is associated with high ambulatory blood pressure and increased carotid intimal-medial thickness. J Pediatr. 2005;147(5): 651-656.

66. Urbina EM, Kimball TR, McCoy CE, Khoury PR, Daniels SR, Dolan LM. Youth with obesity and obesity-related type 2 diabetes mellitus demonstrate abnormalities in carotid structure and function. Circulation. 2009;119(22):2913-2919.

67. Riva P, Martini G, Rabbia F, et al. Obesity and autonomic function in adolescence. Clin Exp Hypertens. 2001;23(1-2):57-67.

68. Thayer JF, Yamamoto SS, Brosschot JF. The relationship of autonomic imbalance, heart rate variability and cardiovascular disease risk factors Int J Cardiol. 2010;141(2):122-131.

69. Bigger JT Jr, Fleiss JL, Steinman RC, Rolnitzky LM, Kleiger RE, Rottman JN. Frequency domain measures of heart period variability and mortality after myocardial infarction. Circulation. 1992;85(1):164-171.

70. Kleiger RE, Miller JP, Bigger JT Jr, Moss AJ. Decreased heart rate variability and its association with increased mortality after acute myocardial infarction. Am J Cardiol. 1987;59(4):256-262.

71. Araujo F, Yamada AT, Markus MR, Antelmi I, Latorre Mdo R, Mansur AJ. Gender-related associations of increased body mass index with clinical and laboratory variables in individuals with no evidence of heart disease. Arq Bras Cardiol. 2007;88(6):624-629. Portuguese.

72. Ojala T, Aaltonen J, Siira S, et al. Fetal cardiac sympathetic activation is linked with maternal body mass index. Early Hum Dev. 2009;85(9):557-560.

73. Bibbins-Domingo K, Coxson P, Pletcher MJ, Lightwood J, Goldman L. Adolescent overweight and future adult coronary heart disease. $N \mathrm{Engl}$ J Med. 2007;357(23):2371-2379. 
74. Barlow SE, Expert Committee. Expert committee recommendations regarding the prevention, assessment, and treatment of child and adolescent overweight and obesity: summary report. Pediatrics. 2007;120(Suppl 4):S164-S192.

75. Daniels SR, Arnett DK, Eckel RH, et al. Overweight in children and adolescents: pathophysiology, consequences, prevention, and treatment. Circulation. 2005;111(15):1999-2012.

76. Daniels SR, Jacobson MS, McCrindle BW, Eckel RH, Sanner BM. American Heart Association Childhood Obesity Research Summit Report. Circulation. 2009;119(15):e489-e517.

77. Farpour-Lambert NJ, Aggoun Y, Marchand LM, Martin XE, Herrmann FR, Beghetti M. Physical activity reduces systemic blood pressure and improves early markers of atherosclerosis in pre-pubertal obese children. J Am Coll Cardiol. 2009;54(25):2396-2406.
78. Huelsing J, Kanafani N, Mao J, White NH. Camp jump start: effects of a residential summer weight-loss camp for older children and adolescents. Pediatrics. 2010;125(4):e884-e890.

79. Tilg H, Kaser A. Gut microbiome, obesity, and metabolic dysfunction. $J$ Clin Invest. 2011;121(6):2126-2132.

80. Vael C, Desager K. The importance of the development of the intestinal microbiota in infancy. Curr Opin Pediatr. 2009;21(6):794-800.

\section{Publish your work in this journal}

Pediatric Health, Medicine and Therapeutics is an international, peerreviewed, open access journal publishing original research, reports, editorials, reviews and commentaries. All aspects of health maintenance, preventative measures and disease treatment interventions are addressed within the journal. Practitioners from all disciplines are invited to submit their work as well as healthcare researchers and patient support groups. The manuscript management system is completely online and includes a very quick and fair peer-review system. Visit http://www.dovepress. com/testimonials.php to read real quotes from published authors.

Submit your manuscript here: http://www.dovepress.com/pediatric-health-medicine-and-therapeutics-journal 